\title{
Remote recruitment for Essential Coaching for Every Mother
}

\section{during COVID-19}

\section{Justine Dol ${ }^{1 *}$, Gail Tomblin Murphy ${ }^{2}$, Douglas McMillan, ${ }^{3}$ Megan Aston, ${ }^{4}$ Marsha}

4 Campbell-Yeo ${ }^{4}$

$5 \quad{ }^{1}$ Faculty of Health, Dalhousie University, Halifax, NS, Canada

$6 \quad 2$ Nova Scotia Health Authority, Halifax, NS, Canada

$7 \quad{ }^{3}$ Department of Pediatrics, IWK Health Centre \& Dalhousie University, Halifax, Canada

$8{ }^{4}$ School of Nursing, Dalhousie University, Halifax, Canada

$9 *$ Correspondence:

10 Justine Dol, Faculty of Health, Dalhousie University, Halifax, NS, Canada, Justine.Dol@ dal.ca

12 Conflict of Interest

13 The authors declare that the research was conducted in the absence of any commercial or

14 financial relationships that could be construed as a potential conflict of interest.

\section{Author Contributions}

16 Author JD conceptualized the manuscript, conducted the data collection, wrote the manuscript, 17 and edited all revisions. Authors MCY, GTM, MA and DM intellectually contributed to the

18 development and writing of the manuscript, added text, and edited all revisions.

\section{Funding}

20 Funding for this project was from a Canadian Institute of Health Research Doctoral Award to

21 Honour Nelson Mandela (FRN154341) and a BRIC NS Student Research Award which were

22 awarded to JD. 
medRxiv preprint doi: https://doi.org/10.1101/2021.03.09.21253071; this version posted May 21, 2021. The copyright holder for this preprint (which was not certified by peer review) is the author/funder, who has granted medRxiv a license to display the preprint in perpetuity.

It is made available under a Remote Recruitment of ECEM in COVID-19

\section{Abstract}

25 Background: With a decrease in in-person support and increase in perinatal mental health

26 concerns during the coronavirus pandemic, innovative strategies, such as mHealth, are more

27 important than ever. However, due to physical distancing recommendations, recruitments for

28 perinatal research needs to shift. The objective of this study is to desire the process evaluation of

29 recruitment and retention of women for an mHealth pre-post intervention study for Essential

30 Coaching for Every Mother.

31 Methods: Three methods were used for recruitment: social media, posters in hospital, and media

32 outreach. First time mothers were eligible for enrollment antenatally (37+ weeks) and postnatally

33 (<3 weeks). Eligibility screening occurred remotely via text message. Outcomes were days to

34 recruit 75 participants, eligibility vs. ineligibility rates, dropout and exclusion reasons, survey

35 completion rates, perinatal timing of enrollment, and recruitment sources.

36 Results: Recruitment ran July $15^{\text {th }}$-September $19^{\text {th }}$ (67 days) with 200 screened and 88 enrolled,

$3770 \%$ antenatally. It took 50 days to enroll 75 participants. Mothers recruited antenatally $(\mathrm{n}=53)$

38 were more likely to receive all intervention message (68\% vs. $19 \%)$. Mothers recruited

39 postnatally $(n=35)$ missed more messages on average (13.8 vs. 6.4). Participants heard about the

40 study through family/friends (31\%), news (20\%), Facebook groups (16\%), Facebook ads (14\%),

41 posters $(12 \%)$, or other ways $(7 \%)$.

42 Conclusion: Antenatal recruitment resulted in participants enrolling earlier and receiving more

43 of the study messages. Word of mouth and media outreach were successful, followed by

44 advertisement on Facebook. Remote recruitment was a feasible way to recruit for Essential

45 Coaching for Every Mother.

46 Keywords: COVID-19; postpartum; mHealth; feasibility; postnatal education, 
medRxiv preprint doi: https://doi.org/10.1101/2021.03.09.21253071; this version posted May 21, 2021. The copyright holder for this preprint

(which was not certified by peer review) is the author/funder, who has granted medRxiv a license to display the preprint in perpetuity.

It is made available under a CC-BY-NC 4.0 International license of ECEM in COVID-19

Irrespective of a pandemic, mothers living in Nova Scotia and beyond face gaps in access

to information and often struggle to find adequate support during the postpartum period, defined

as the first six weeks after birth. ${ }^{1-3}$ These gaps may be magnified during the coronavirus

50 pandemic and may significantly impact the transition for new mothers. ${ }^{4,5}$ Compliance with

51 physical distancing recommendations contribute to mothers isolating at home, being physically

52 isolated from not only health providers, but also from their extended family and support

53 systems. ${ }^{4}$ In Nova Scotia, all public health drop-ins were closed indefinitely, there was a

54 reduction in in-person healthcare support, and midwifery-led home births and home visits were

55 temporarily deferred during the coronavirus peak from March to May $2020{ }^{6}$ This significantly

56 differed from pre-coronavirus procedures, where mothers were recommended to have a postnatal

57 contact shortly after birth by a public health nurse ${ }^{7}$ and mothers frequently engaged in visits with

58 family, friends, or new parent groups. ${ }^{8,9}$ Emerging evidence shows that the pandemic has

59 resulted in $37-54 \%$ of mothers experiencing perinatal depression and $57-72 \%$ experiencing

60 symptoms of perinatal anxiety. ${ }^{10,11}$ With the sudden decrease in in-person support and the

61 increase in perinatal mental health concerns, innovative strategies, such as mHealth, are more

62 important than ever to offer information and support during the postpartum period.

Prior to the coronavirus outbreak, the Essential Coaching for Every Mother program was

64 developed to send daily text messages to mothers during the immediate six-week postpartum

65 period. ${ }^{12}$ However, given the requirement of physical distancing and limitations on the number

66 of visitors in hospital, exploration was needed on the ability to recruitment remotely rather than

67 the traditional, in-person approach for a planned randomized control trial. Therefore, this study

68 sought to explore the feasibility of remote recruitment of pregnant and postpartum women for the

69 Essential Coaching for Every Mother pre-post intervention study. 
medRxiv preprint doi: https://doi.org/10.1101/2021.03.09.21253071; this version posted May 21, 2021. The copyright holder for this preprint (which was not certified by peer review) is the author/funder, who has granted medRxiv a license to display the preprint in perpetuity.

It is made available under a Remote Recruitment of ECEM in COVID-19

Methods

\section{$71 \quad$ Research Design}

This study uses a cross-sectional pre-post design.

\section{Study Population \& Sample Size}

Between 2017 and 2019 at the IWK Health Centre, 4,055 primiparous women gave

mothers would be available. To determine feasibility of recruitment, the goal was to recruit at

77 least $15 \%$ of this sample $(n=75)$ within three months. The recruitment goal for the randomized

78 controlled trial is 140 participants, ${ }^{14}$ so this estimated sample size was approximately half of

79 what would be required.

80 To participate, women must (1) have given birth to their first baby at IWK Health and

81 live in Nova Scotia; (2) have daily access to a mobile phone with text message capabilities; (3)

82 be over 18 years of age; and (4) speak and read English. Women were eligible to enrol

83 antenatally if they were at least 37 weeks pregnant and had not yet given birth. The antenatal

84 time limitation was set to ensure participants would deliver within the three-month recruitment

85 period. Women were eligible to enrol postnatally up to 21 days following the birth of their child.

86 The postpartum limit was set to ensure there was a least a three-week gap between baseline and

87 6-week follow-up surveys and to ensure participants received enough of the message to provide

88 evaluative feedback.

\section{Intervention}

Essential Coaching for Every Mother is a six-week postpartum text message program that

91 was previously developed in consultation with postpartum mothers and healthcare providers with

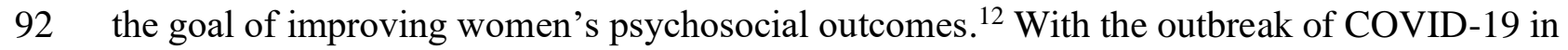


medRxiv preprint doi: https://doi.org/10.1101/2021.03.09.21253071; this version posted May 21, 2021. The copyright holder for this preprint

(which was not certified by peer review) is the author/funder, who has granted medRxiv a license to display the preprint in perpetuity.

It is made available under a CC-BY-NC 4.0 International license of ECEM in COVID-19

93 early 2020 and the readiness of the Essential Coaching for Every Mother program to fill the

94 sudden gap in postpartum support, a decision was made to modify the program to be offered

95 immediately. Given that Essential Coaching for Every Mother was developed prior to the

96 coronavirus outbreak but not previously implemented, some modifications were necessary. To

97 ensure that the revised content of Essential Coaching for Every Mother was appropriate and

98 acceptable, the modified messages were piloted with mothers and postpartum healthcare

99 providers who participated in the original development of the program. Messages were updated

100 using the Government of Canada and World Health Organization guidelines around mother-

101 infant care and coronavirus ${ }^{15,16}$ and followed the Government of Nova Scotia public health

102 guidelines during the coronavirus pandemic. ${ }^{17}$

103 Nine messages were modified from the original program to include information related to

104 the coronavirus, of which four messages were collapsed into two, and five messages were added

105 to the program. This resulted in a total of 56 messages, with messages provided two or three

106 times per day during the two weeks, and daily for the remaining four weeks. Figure 1 provides

107 an example of two messages included. The first message of Essential Coaching for Every

108 Mother is designed to start the evening of the second day after giving birth. If a participant

109 signed up beyond this time frame, they started the messages based on when they delivered.

\section{Recruitment Procedures}

111 Three primary methods of recruitment were used: social media, posters in the hospital,

112 and media outreach. First, social media advertisements were used including paid Facebook and

113 Instagram advertisements, sharing in relevant Facebook groups, and tweets on Twitter. Social

114 media outreach and paid advertisements started on July $15^{\text {th }}$ and ran until August 16 ${ }^{\text {th }}, 2020$.

115 Second, posters were placed in the IWK Health Perinatal Clinic and in each room on the Family 
medRxiv preprint doi: https://doi.org/10.1101/2021.03.09.21253071; this version posted May 21, 2021. The copyright holder for this preprint

(which was not certified by peer review) is the author/funder, who has granted medRxiv a license to display the preprint in perpetuity.

It is made available under a Remote Recruitment of ECEM in COVID-19

116 Newborn Unit. Posters were placed on August $5^{\text {th }}$ and taken down on September $15^{\text {th }}$. Finally,

117 media interviews also occurred with the first author after a media release was published by IWK

118 Health on August 5 $5^{\text {th }}, 2020$.

All eligibility screening occurred remotely via text message through the TextIt platform ${ }^{18}$

120 with interested participants initiating contact. Pregnant women started the recruitment process by

121 texting 'pregnant' to the study number and proceeded through the antenatal eligibility screening

122 process. Eligible mothers were instructed to text 'delivered' after giving birth to be enrolled in

123 the study. Women received reminder messages to text 'delivered' at 39 weeks, 40 weeks, 41

124 weeks and 42 weeks if they had not yet enrolled or withdrawn. Mothers who were deemed

125 ineligible as part of the antenatal screening due to being less than 37 weeks were sent a message

126 to remind them to text 'pregnant' if they were still interested. This occurred until August $27^{\text {th }}$

127 when the number of interested and enrolled participants was beyond the desired 75 participants.

128 Postpartum women who initiated contact using 'birth' proceeded through the postpartum

129 eligibility flow. Once deemed eligible, postpartum participants and antenatal women who texted

130 'delivered' completed the same flow to be enrolled in the study and start receiving messages

131 based on their delivery date. During this phase, details about newborn's name, preferred gender

132 pronoun, date of birth, mother's name, and preference for breastfeeding or formula messages

133 were collected. This was used to personalize the messages with names and ensure messages were

134 sent based on child's age and preference for breastfeeding or formula messages.

135 Participants were asked to complete a consent form and survey at baseline (survey \#1)

136 and once the messages ended at 6-weeks (survey \#2). Participants were reminded about the

137 surveys via text message six times (every 2 days) at each timepoint or until they completed the

138 full survey. After 14 days, participants who had yet to complete the full survey were sent an 
medRxiv preprint doi: https://doi.org/10.1101/2021.03.09.21253071; this version posted May 21, 2021. The copyright holder for this preprint

(which was not certified by peer review) is the author/funder, who has granted medRxiv a license to display the preprint in perpetuity.

It is made available under a CC-BY-NC 4.0 International license of ECEM in COVID-19

email or text as a final reminder and it was assumed to be incomplete if a participant did not complete after this point. Participants who completed the full survey received a $\$ 20$ electronic gift card at each survey timepoint. Figure 2 outlines of study enrollment and participation flow. While messages were only one-way, if a mother responded with a question of clarification during recruitment or related to the survey, the first author responded to provide clarification only. No responses to the Essential Coaching for Every Mother messages occurred.

\section{Intervention Procedures}

TextIt ${ }^{18}$ was used as the platform to develop the message flows and capture participant contact information. It was used in conjunction with Twilio ${ }^{19}$ the server that sent and received the messages. Survey data were collected via REDCap. ${ }^{20}$ Contact information was collected via TextIt which was kept separate from survey data collected via REDCap. Ethics approval was obtained by the IWK Health Centre (\#1024984). All women provided written, online consent. To determine feasibility, data on implementation extent was collected via output data available through the TextIt platform as well as REDCap. Specifically, the following outcomes were of interest: (1) number of days required to recruit at least 75 participants; (2) eligibility vs. ineligibility rates and reasons; (3) dropout, exclusion, and baseline survey completion rates; (4) enrollment rates based on antenatal or postnatal recruitment; and (5) recruitment sources. For the outcomes identified above, the following information was used: Days required to recruit participants was the number of days from start of study to enrollment of 75 participants, total number of participants enrolled, and time required for recruitment. Eligibility vs. ineligibility rates was the number of individuals who were eligible and enrolled in the study vs. the number of individuals who contacted but were not eligible (comparing both antenatal and postpartum ineligibility and reasons). Dropout \& survey completion rates was the number of participants 
medRxiv preprint doi: https://doi.org/10.1101/2021.03.09.21253071; this version posted May 21, 2021. The copyright holder for this preprint (which was not certified by peer review) is the author/funder, who has granted medRxiv a license to display the preprint in perpetuity.

It is made available under a Remote Recruitment of ECEM in COVID-19

162 who withdrew or were excluded from the study and when (\% completion, timing of withdraw).

163 Enrollment based on antenatal vs. postnatal recruitment compared number and timing of

164 enrollment (number of messages received, infants age at enrollment, time of day of initial

165 contact). Recruitment sources were participant's self-reported source of where they heard about

166 the study.

167 Analysis

168

Descriptive and summative analysis of TextIt and REDCap event data was used to

169 examine the frequency and proportion of outcomes above.

Results

171 Participants

172 Of the 80 women who completed the demographic survey, they were on average 30.8

173 years of age (standard deviation $[S D]=4.7$ ). The sample was quite homogeneous $-98.8 \%$ had

174 singleton births, $91.3 \%$ identified as heterosexual, $87.5 \%$ were white, and $93.8 \%$ were either

175 married or common-law. Over half (51.8\%) had a household income over \$100,000CAN.

176 Women were on average 39.3 weeks pregnant when they gave birth $(\mathrm{SD}=1.5$ weeks, range $=33.5$ -

17742 weeks).

178 Timing required to recruit participants

179 The study opened on July 15, 2020, and closed September 19, 2020. Over this 67 days,

18096 participants were enrolled in the program and were assigned a study identification number.

181 Timing to enroll 75 participants (our initial target) took 50 days.

182 Eligibility vs. ineligibility

183 A total of 200 'pregnant' or 'birth' messages were sent to the study contact number by

184 potential participants during the recruitment period. Figure 3 outlines the perinatal timing and 
medRxiv preprint doi: https://doi.org/10.1101/2021.03.09.21253071; this version posted May 21, 2021. The copyright holder for this preprint

(which was not certified by peer review) is the author/funder, who has granted medRxiv a license to display the preprint in perpetuity.

It is made available under a CC-BY-NC 4.0 International license of ECEM in COVID-19

185

186

187

188

189

190

191

192

193

194

195

196

197

198

199

200

201

202

203

204

205

206

207

reasons for ineligibility. 140 participants initiated contact antenatally and 60 initiated contact in the postpartum period. For the antenatal participants, 30 were not eligible, seven were not interested, and 45 were excluded not being based in Nova Scotia. For the postpartum period, 20 were not eligible and two were not interested.

We excluded 45 contacts who were not based in Nova Scotia and were using a United States (US) number. We initially thought this could be individuals who are temporarily residing in Canada since they provided valid Nova Scotia postal codes in the demographic questionnaire. However, upon further analysis, we believe these were not actual mothers from the US wanting to participate due to a discrepancy in the standardized questionnaire responses with extremely high scores on these measures (well beyond the standard mean) and quick completion time of their REDCap surveys (immediately after they enrolled and on their delivery date), suggesting these were not actual participants. When analyzing location through Twilio, the US had a predominant send/receive rate, providing further evidence that these respondents were not in Canada. Therefore, with the triangulation of these findings, it was deemed that these responses are not actual potential participants and if they were, they were not residing in Nova Scotia as required by the study protocol, and thus were excluded.

\section{Dropout \& survey completion rates}

Of the 96 enrolled participants, four withdrew from the program after receiving 0, 5, 6 and 9 messages respectively (Mean $[M]=4, S D=3.7$ ). Three of the participants who withdrew enrolled in the postpartum period and one enrolled antenatally. As none of the participants who withdrew completed the baseline survey, we were unable to determine if these participants were different from those who completed the program. Four participants did not complete any aspect of the baseline survey, thus were excluded from the analysis. 
medRxiv preprint doi: https://doi.org/10.1101/2021.03.09.21253071; this version posted May 21, 2021. The copyright holder for this preprint (which was not certified by peer review) is the author/funder, who has granted medRxiv a license to display the preprint in perpetuity.

It is made available under a Remote Recruitment of ECEM in COVID-19

Therefore, the study had a total of 88 participants who did not opt out and who completed

209 at least some of the baseline survey. Ninety percent $(90.1 \%)$ of participants completed the full

210 baseline survey, on average 5.0 days from enrollment (Median $=3$ days, $\mathrm{SD}=5.3$ days, range 0-

21119 days). Nine percent $(n=8)$ did not complete baseline survey in full - on average, participants

212 completed $56.25 \%$ of the survey (range: $25 \%-75 \%$ ).

$213 \quad$ Timing of recruitment

214 Of the 88 participants who were enrolled, $42(47.7 \%)$ received full messages. Of these,

21536 were antenatally recruited and six were recruited postnatally. Late enrollment during the

216 antenatal period resulted in missing on average 6.4 messages $(\mathrm{SD}=6.2)$ whereas late enrollment

217 during the postpartum period resulted in missing on average 13.8 messages $(\mathrm{SD}=10.6)$.

\section{$218 \quad$ Recruitment sources}

Among the 80 participants who completed the full survey, $30.5 \%(n=25)$ heard about the

220 study through friends or family and $18.3 \%(n=15)$ heard about it on the news. Recruitment via

221 Facebook was also successful, with a quarter of participants reached through the social media

222 platform - 14.6\% via Facebook groups, 13.4\% via Facebook advertisements, and 1.2\% via

223 Facebook Marketplace. No participant reported hearing about it through Instagram or Twitter.

224 Posters in the hospital was the source of recruitment for $14.6 \%$ of participants, with $7.6 \%$ saying

225 other (including doula, social media broadly, hospital website, and no response).

For paid Facebook advertisements, a total of $\$ 215.77$ Canadian was spent, which equals a

227 cost of \$19.62 per enrolled participants who indicated this a primary recruitment method.

228 However, this may not be accurate as this does not consider whether any friends or family heard

229 about the study through paid advertisements.

\section{Discussion}


medRxiv preprint doi: https://doi.org/10.1101/2021.03.09.21253071; this version posted May 21, 2021. The copyright holder for this preprint

(which was not certified by peer review) is the author/funder, who has granted medRxiv a license to display the preprint in perpetuity.

It is made available under a CC-BY-NC 4.0 International license of ECEM in COVID-19

This study describes the remote recruitment of Essential Coaching for Every Mother as a

232 pilot pre-post intervention study. The online and remote recruitment of pregnant and postpartum

233 women for a pre-post intervention study for Essential Coaching for Every Mother was a success

234 as we were able to recruit over our target of 75 participants within 50 days, with recruitment

235 suspended within 67 days due to significant interest. This suggests that mothers were interested

236 in receiving information during the postpartum period, which may have been enhanced due to

237 the pandemic.

Emerging evidence shows that the pandemic has resulted in $37-54 \%$ of mothers

experiencing perinatal depression and 57-72\% experiencing symptoms of perinatal anxiety, ${ }^{10,11}$

240 suggesting that a preventative mHealth program for mothers could have a positive effect on

241 mothers postpartum adjustment and experience. Given the growing evidence of the mental health

242 consequences of physical distancing recommendations, ${ }^{21}$ particularly during an intensely

243 vulnerable period as is the postpartum period, having evidence-based information provided via

244 text message may help cover this gap. Digital health during COVID-19 has the potential to

245 bridge the healthcare service gap while maintaining physical distancing recommendations. ${ }^{22,23}$

246 We found that mothers who were recruited antenatally received more of the study

247 messages than participants who were recruited postnatally, with the latter missing on average 7.4

248 messages more. As participants who initiated contact during the antenatal period were sent

249 reminder messages starting at 39 weeks, they were more likely to enroll earlier than mothers who

250 had already delivered. No mother who expressed interest during the antenatal period and was

251 deemed eligible failed to enroll. Thus, antenatal recruitment may be a more efficient way to

252 target recruitment for the larger clinical trial to ensure mothers receive as much of the program as

253 possible. Additionally, given the delay in baseline survey completion after delivery, shifting to 
medRxiv preprint doi: https://doi.org/10.1101/2021.03.09.21253071; this version posted May 21, 2021. The copyright holder for this preprint

(which was not certified by peer review) is the author/funder, who has granted medRxiv a license to display the preprint in perpetuity.

It is made available under a Remote Recruitment of ECEM in COVID-19

254 have participants complete the baseline survey upon enrollment and prior to delivery may result

255 in more timely completion than during the postpartum period.

256 Looking at the direct recruitment methods, the most successful approach was promotion

257 through Facebook. Both advertisement through mother-focused Facebook groups and paid

258 advertisements were similarly effective. This finding is supported by previous systematic

259 reviews which found that Facebook recruitment was an effective way to reach participants for

260 health research. ${ }^{24,25}$ Within our study, we also found that sharing the study in the media and news

261 reached $17 \%$ of participants and posters in the hospital reached $13.6 \%$ of participants, which

262 suggests that using a multi-pronged approach to recruitment is more efficient than solely using

263 social media.

264 Limitations

265 Despite the successes, there were some challenges in recruitment. First, most participants

266 heard about the study through family and friends, but it is unclear how these family and friends

267 heard about it. Additionally, we were unable to gather how mothers who contacted us but did not

268 enroll in the study heard about it. Both of these factors limit the interpretation of recruitment

269 source analysis. A second challenge was the high potential for people to misuse the self-

270 identification of eligibility screening which occurred exclusively via text message. This occurred

271 in relation to the large number of US-based numbers. We hypothesize that someone(s) had been

272 completing the eligibility screening and baseline questionnaire to gain access to the honorarium.

273 While TextIt cannot limit to provincial locations, we continued to monitor recruitment closely to

274 ensure we identified any issues related to this through regularly monitoring of area codes. This

275 may have potentially excluded individuals who were residing in Nova Scotia but had US

276 numbers, this was required to ensure safety and adherence to study protocol inclusion criteria. 
278 recognized as a limitation and is consistent with online recruitment. ${ }^{24}$ Further work should have a

279 more direct focus on collecting a diverse sample.

\section{Conclusion}

281 Despite these challenges, this study found that Essential Coaching for Every Mother was able to

282 successfully use remote recruitment of pregnant and postpartum women for a pre-post

283 intervention study using a variety of recruitment sources. Findings from this study will be

284 applied in the randomized controlled trial. ${ }^{14}$ 
medRxiv preprint doi: https://doi.org/10.1101/2021.03.09.21253071; this version posted May 21, 2021. The copyright holder for this preprint (which was not certified by peer review) is the author/funder, who has granted medRxiv a license to display the preprint in perpetuity.

It is made available under a Remote Recruitment of ECEM in COVID-19

\section{References}

287 1. Deave T, Johnson D, Ingram J. Transition to parenthood: The needs of parents in pregnancy and early parenthood. BMC Pregnancy Childbirth. 2008;8:1-11.

289 2. Martin A, Horowitz C, Balbierz A, Howell EA. Views of women and clinicians on 290 postpartum preparation and recovery. Matern Child Health J. 2014;18(3):707-13.

$2913 . \quad$ Chalmers B, Dzakpasu S, Heaman M, Kaczorowski J. The Canadian Maternity Experiences Survey: An Overview of Findings. J Obstet Gynaecol Canada. 2008;30(3):217-28.

294 4. Dol J, Richardson B, Aston M, Mcmillan D, Tomblin murphy G, Campbell-yeo M.

5. Ollivier R, Aston DM, Price DS, Sim DM, Benoit DB, Joy DP, et al. Mental Health \&

Eastern Canada: A mixed method cohort study. medRxiv [Internet]. 2021 Jan 1;2021.01.30.21250555. Available from:

6. Nova Scotia Health Authority. Temporary service and facility closure notices from Nova http://www.nshealth.ca/temporary-service-and-facility-closure-notices-nova-scotia-health-

307 7. Reproductive Care Program of Nova Scotia. Healthy Babies, Healthy Families: 
medRxiv preprint doi: https://doi.org/10.1101/2021.03.09.21253071; this version posted May 21, 2021. The copyright holder for this preprint

(which was not certified by peer review) is the author/funder, who has granted medRxiv a license to display the preprint in perpetuity.

It is made available under a CC-BY-NC 4.0 International license of ECEM in COVID-19

http://novascotia.ca/dhw/publications/Public-Health-Education/Postpartum Guidelines.pdf

310 8. Aston M, Price S, Monaghan J, Sim M, Hunter A, Little V. Navigating and negotiating information and support: Experiences of first-time mothers. J Clin Nurs. 2018;27(3-

9. Johnson SA. 'Intimate mothering publics': comparing face-to-face support groups and Internet use for women seeking information and advice in the transition to first-time motherhood. Cult Health Sex. 2015;17(2):237-51.

10. Davenport M, Meyer S, Meah VL, Strynadka MC, Khurana R. Moms are not OK: COVID-19 and maternal mental health. Front Glob Women's Heal. 2020;1(June):1-6.

318 11. Lebel C, MacKinnon A, Bagshawe M, Tomfohr-Madsen L, Giesbrecht G. Elevated depression and anxiety among pregnant individuals during the COVID-19 pandemic. J

321 12. Dol J, Tomblin G, Aston M, Mcmillan D, Campbell-yeo M. Design, development and usability testing of Essential Coaching for Every Mother: A postnatal text message educational intervention. Women and Birth. 2020;(2019).

324 13. Reproductive Care Program of Nova Scotia. The Nova Scotia Atlee Perinatal Database. Halifax; 2020.

14. Dol J, Aston M, Mcmillan D, Tomblin Murphy G, Campbell-Yeo M. Effectiveness of a 2021;10(3):1-10.

15. World Health Organization. Pregnancy, Childbirth, breastfeeding and COVID-19 [Internet]. Webpage. 2020 [cited 2020 Aug 17]. Available from: 
medRxiv preprint doi: https://doi.org/10.1101/2021.03.09.21253071; this version posted May 21, 2021. The copyright holder for this preprint (which was not certified by peer review) is the author/funder, who has granted medRxiv a license to display the preprint in perpetuity. It is made available under a Remote Recruitment of ECEM in COVID-19

https://www.who.int/reproductivehealth/publications/emergencies/COVID-19-pregnancyipc-breastfeeding-infographics/en/

334 16. Government of Canada. COVID-19: Pregnancy, childbirth and caring for newborns:

335 Advice for mothers [Internet]. Webpage. 2020 [cited 2020 Aug 17]. Available from:

336 https://www.canada.ca/en/public-health/services/publications/diseases-

$337 \quad$ conditions/pregnancy-advise-mothers.html

338 17. Government of Nova Scotia. Novel coronavirus (COVID-19) [Internet]. Webpage. 2020 [cited 2020 Aug 17]. Available from: https://novascotia.ca/coronavirus/

340 18. TextIt. TextIt [Internet]. Webpage. 2017 [cited 2018 May 3]. Available from:

$341 \quad$ http://textit.in

342 19. Twilio. Twilio [Internet]. 2018 [cited 2018 Oct 24]. Available from:

343 https://www.twilio.com

344 20. Harris PA, Taylor R, Thielke R, Payne J, Gonzalez N, Conde JG. Research electronic data capture (REDCap) - A metadata-driven methodology and workflow process for providing translational research informatics support. J Biomed Inf. 2009;42(2):377-81.

347 21. Galea S, Merchant R, Lurie N. The Mental Health Consequences of COVID-19 and 2020;180(6):817-8.

22. Torous J, Myrick KJ, Rauseo-Ricupero N, Firth J. Digital mental health and COVID-19:

353 23. Fagherazzi G, Goetzinger C, Rashid MA, Aguayo GA, Huiart L. Digital health strategies 354 to fight COVID-19 worldwide: Challenges, recommendations, and a call for papers. J 
Med Internet Res. 2020;22(6).

356 24. Whitaker C, Stevelink S, Fear N. The use of Facebook in recruiting participants for health

357 research purposes: A systematic review. J Med Internet Res. 2017;19(8).

358 25. Thornton L, Batterham PJ, Fassnacht DB, Kay-Lambkin F, Calear AL, Hunt S. Recruiting

359 for health, medical or psychosocial research using Facebook: Systematic review. Internet

$360 \quad$ Interv. 2016;4:72-81.

361

362 
medRxiv preprint doi: https://doi.org/10.1101/2021.03.09.21253071; this version posted May 21, 2021. The copyright holder for this preprint (which was not certified by peer review) is the author/funder, who has granted medRxiv a license to display the preprint in perpetuity.

\section{It is made available under Remote Recruitment of EECEM in COVID-19}

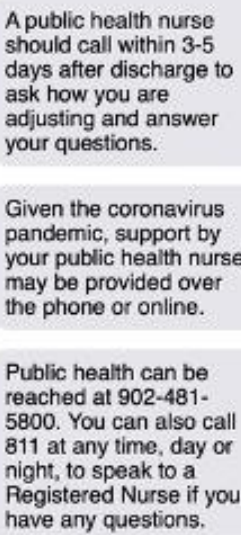

Figure 1. Examples of Essential Coaching for Every Mother messages relevant to COVID-19.

367 The first is a message that was revised to reflect the current standard of care in postnatal follow-

368 up by a public health nurse which increased from within 48 hours to 3-5 days and may occur

369 over the phone or online rather than in person. The second message is an example of a message

370 that was added related specifically to postnatal care during COVID-19. 
medRxiv preprint doi: https://doi.org/10.1101/2021.03.09.21253071; this version posted May 21, 2021. The copyright holder for this preprint (which was not certified by peer review) is the author/funder, who has granted medRxiv a license to display the preprint in perpetuity.

It is made available under a CC-BY-NC 4 . International license of ECEM in COVID-19

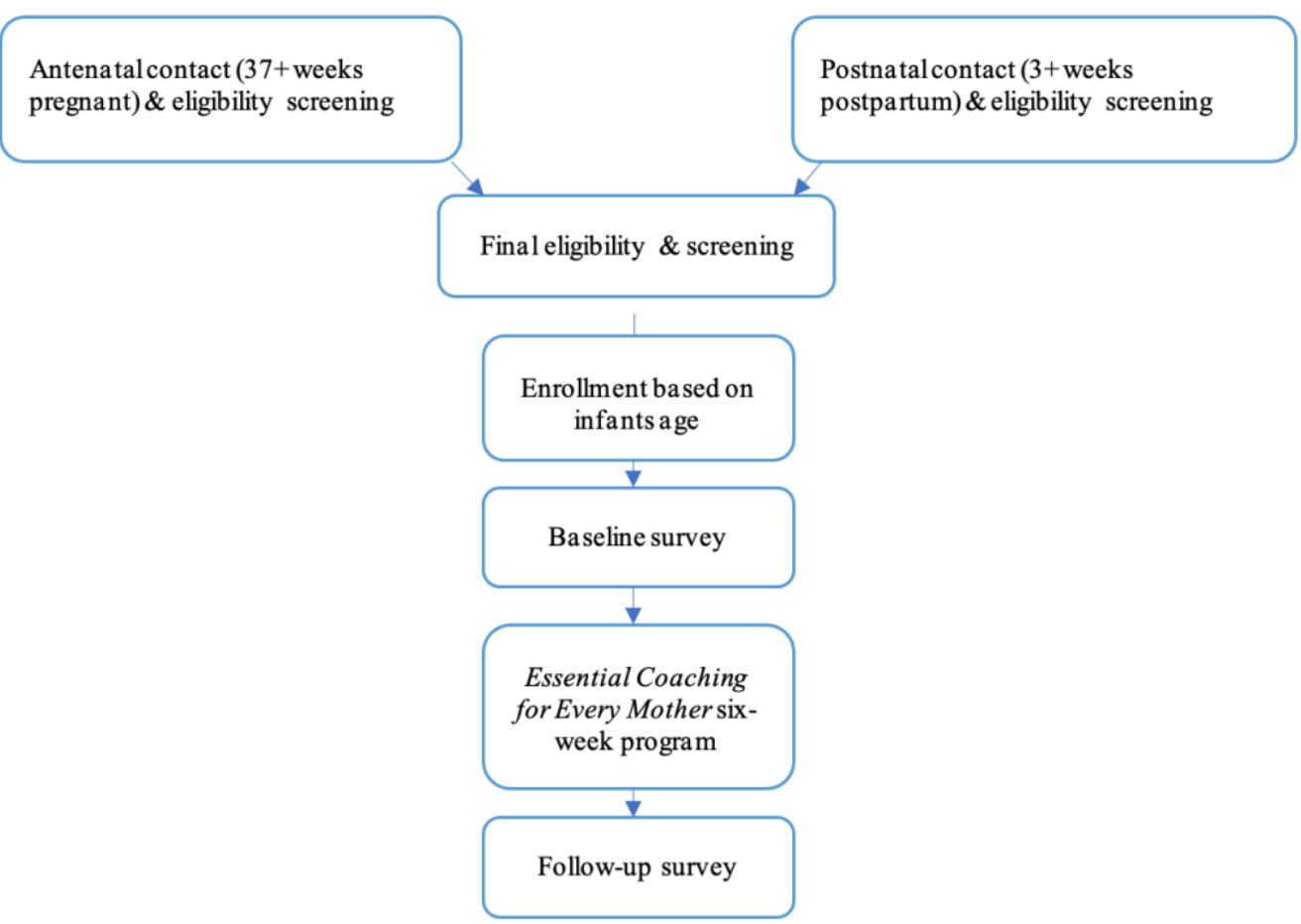

373

374 Figure 2. Study enrollment and participation flow diagram

375

376

377

378

379

380

381 
medRxiv preprint doi: https://doi.org/10.1101/2021.03.09.21253071; this version posted May 21, 2021. The copyright holder for this preprint (which was not certified by peer review) is the author/funder, who has granted medRxiv a license to display the preprint in perpetuity.

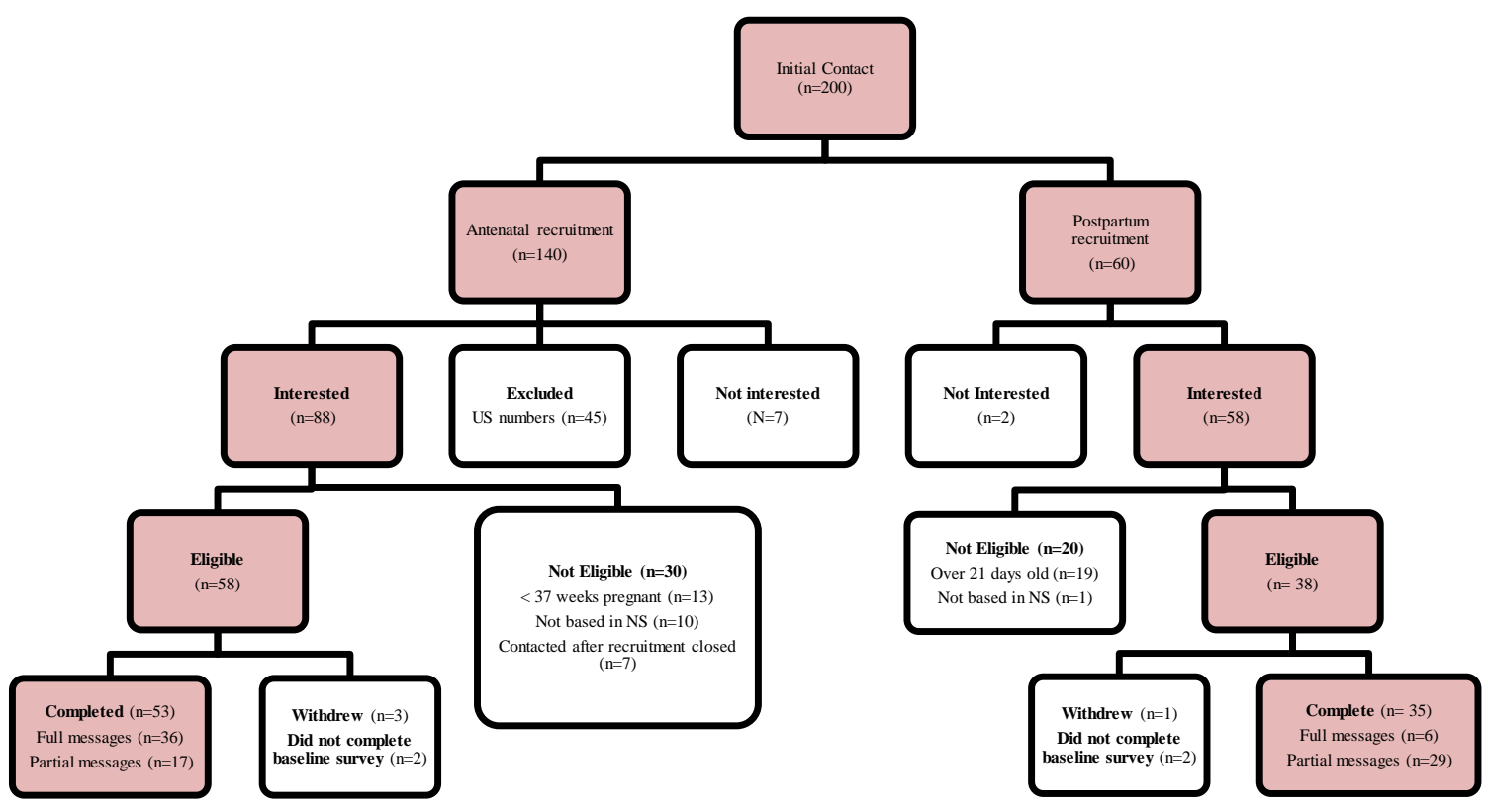

385 Figure 3. Enrollment flow 